\title{
Using Learning Centers to Improve the Language and Academic Skills of Preschool Children
}

\author{
Özgün Uyanık Aktulun ${ }^{1, *} \&$ Gözde İnal Kızıltepe ${ }^{2}$ \\ ${ }^{1}$ Faculty of Education, Afyon Kocatepe University, Afyonkarahisar, Turkey \\ ${ }^{2}$ Faculty of Education, Adnan Menderes University, Aydın, Turkey \\ *Correspondence: Faculty of Education, Afyon Kocatepe University, Afyonkarahisar, Turkey. Tel: 90-272-228-1418. \\ E-mail: ozgunuyanik@hotmail.com
}

Received: November 13, $2018 \quad$ Accepted: November 28, $2018 \quad$ Online Published: December 7, 2018

doi:10.5430/wje.v8n6p32 URL: https://doi.org/10.5430/wje.v8n6p32

\begin{abstract}
A mixed-methods research design was employed to investigate the impact of use of learning centers to support language and academic skills of children aged 61-72 months. The sample of quantitative data of the study consisted of 70 children ( 35 in the experimental group and 35 in the control group). In the quantitative dimension of the study, data were collected using the "Kaufman Survey of Early Academic and Language Skills," "Progress in Maths 6 Test," and the "Control List for the Evaluation of the Print Awareness of Pre-School Children" scales. In the qualitative dimension of the study, semi-structured interviews were conducted with the teachers of the experimental group through the "Teacher Interview Form" developed by the researchers. During the implementation period, learning centers were established and organized in such a way that the 35 children in the experimental group could use them for about 75-90 minutes every day for eight weeks. The results obtained from the study reveal that arrangements made in the learning centers provide important contributions to the development of children's language, literacy and mathematics skills.
\end{abstract}

Keywords: preschool period, learning centers, language skills, academic skills, mathematical skills, early literacy skills

\section{Introduction}

Language skills and academic skills, which involve literacy skills and math skills, constitute the basis for school achievement in the years ahead. For this reason, the preschool period is seen as a critical period for the development of children's language and academic skills, and many studies have been carried out for children to gain competence in terms of language and academic skills during this period (Anders et al., 2012; Burchinal, Peisner-Feinberg, Pianta, Howes, 2002; Campbell, Pungello, Miller-Johnson, Burchinal \& Ramey, 2001; Duncan et al.,2007; Son \& Morrison, 2010; Uyanık \& Alisinanoğlu, 2016).

Children in preschool education institutions have different knowledge and skill levels in terms of language and academic skills depending on their home experience (Burchinal et al., 2011; Pelatti, Dynia, Logan, Justice \& Kaderavek, 2016). High-quality educational experiences offered to children in preschool educational environments are of great importance both in terms of reducing individual differences originating from the home environment and increasing academic achievements of children in the future (Barnett, 2011; Howes et al., 2008; Mashburn et al., 2008; Mokrova, Broekhuizen \& Burchinal, 2015).

In recent years, it is possible to come across many studies revealing the effects of preschool educational environments on children's learning, as well as explaining how educational environments should be organized to support children's learning (Backman et al., 2012; Çelebi Öncü, 2017; Dyment \& O'Connell, 2013; Li, 2006; Robinson \& Fraser, 2013). The educational environment, which is regarded as the "third teacher," is of great importance in terms of the quality of educational experiences provided to children in preschool education (Gandini, 1998; Hebert, 1998; Moore \& Sugiyama, 2007). Allen and Fraser (2007) have stated that the educational environment is a contributing factor for children to learn better. They have emphasized that especially when children interact with materials and peers in their preferred learning environments they learn more effectively. In this respect, 
there are learning centers that include various materials and opportunities that allow children to participate in their own choices and gain hands-on learning experience in many preschool environments (Beaty, 2014; Biddle, Garcia-Nevarez, Henderson, Valero-Kerrick, 2013).

Learning centers - also called learning areas, centers of interest or activity centers - are defined as a system used to organize a class or materials in a class (Jackman, Beaver \& Wyatt, 2014; Metin, 2017) and an instructional method used to promote the social and academic development of children (McCarthy, 1977 as cited in Naimoli-Ginter, 2008). Learning centers maximize learning through a variety of tasks and activities that allow children to work and learn at their own pace while, at the same time, allowing them to practice their pre-knowledge (King-Sears, 2007; Texas Workforce Commission, 2002). Devany (2005), Pellegrino (2007) and Kostelnik, Soderman, Whiren, Rupiper (2015) have emphasized that creating learning centers in educational environments allows meeting individual learning needs and having meaningful learning experiences. Hilberg, Chang and Epaloose (2003) have stated that learning centers promote effective participation, collaboration and advanced language and academic skills.

In this context, the most widely seen learning centers in preschool environments are block, art, book, reading and writing, dramatic play, science, music, computer, sand and water centers (Beaty, 2014; Biddle et al., 2013; Jackman et al., 2014; Kandır, Özbey, \& İnal, 2010). It is important to have a certain number and variety of learning centers in preschool environments to provide children with different stimulants and learning opportunities (Conn-Powers, 2010). Moreover, materials in learning centers encourage children to do purposeful research and exploration activities. Teachers are responsible for selecting the materials that are appropriate for the objectives of the curriculum, organizing these materials so that children can reach them, and letting children use these centers and learn through planning (Cohen, Manion, \& Morrison, 2010).

The preschool education curriculum in Turkey, which was updated in 2013, brings a new perspective to teachers in terms of organizing the educational environment. The curriculum recommends the creation of learning centers that can enable children to actively participate and enable teachers to support children's skills through individual or small group studies (Çelebi Öncü, 2017; MEB, 2013). According to the 2013 Preschool Education Curriculum of the Ministry of National Education (MoNE), preschool education institutions should have block, book, music, art, science and dramatic play centers. It is clearly stated in the main features of the curriculum that learning centers are important. In addition to that, detailed information is given about the creation and organization of learning centers, the materials that can be found in these centers and the role of the teacher (MEB [MONE], 2013). However, studies on learning centers in Turkey have clearly revealed that not all the learning centers mentioned in the curriculum have been created in classrooms and that existing learning centers have not been organized to support children's learning (Aysu \& Aral, 2016; Metin, 2017; Öztürk Samur \& İnal Kızıltepe, 2018; Ramazan, Çiftçi \& Tezel, 2018).

When the literature is reviewed, it is seen that there are many studies around the world investigating how learning centers should be organized to support children's skills and learning in different fields (critical thinking, oral language skills and literacy skills, phonological awareness, math skills, reducing aggressive behaviors, and so forth) (DaCunha, 2016; Dahmer, 2010; Naimoli-Ginter, 2008; Pellegrino, 2007; Ramani \& Eason, 2015; Wright, 2016). However, when studies on learning centers in Turkey were examined, it was found that, most of the time, the focus was on studies investigating the types of learning centers that were created in educational environments. From this viewpoint, it was aimed to investigate the impact of learning centers that were created or reorganized in educational environments to support language and academic skills of 61- to 72-month-old children.

\section{Method}

\subsection{Research Design}

In this study, a convergent parallel design was used within the scope of the mixed-method research. The convergent parallel design is formed by simultaneous implementation of quantitative and qualitative phases in the same phase of the research process. This design gives equal priority to the methods, keeps the phases separate from each other during analysis, and then merges the results when making an overall interpretation (Cresswell \& Clark, 2017). In line with this, quantitative and qualitative data were collected simultaneously also in this study.

In the quantitative dimension of the study, a quasi-experimental, pretest-posttest, control group design was used. In the qualitative section of the study, semi-structured interviews were conducted with the teachers of the children in the experimental group. 


\subsection{Sample}

The research population of the study consisted of 61-72 month-old children with normal development, who continued their education at the kindergartens of the Directorate of National Education in Afyonkarahisar Province in the Aegean region of Turkey. For the quantitative data, 70 children (35 in the experimental group and 35 in the control group) aged 5-6 years selected by using the criterion sampling method were included in the sample of the study. In order to determine the sample, the classes of children aged 5-6 years at separate kindergartens of the Directorate of National Education in the provincial center were visited four times at random intervals during a semester. In the classrooms, the learning centers prepared by teachers were observed. Following that, the classrooms that mostly included block and dramatic learning centers, which gave very little space to other learning centers, and where no specific training programs had been implemented on any subject, were identified.

Since the experimental implementation was planned to be carried out especially by the classroom teacher, two classrooms of the kindergarten - selected from among the classrooms that were specified in accordance with the criterion sampling method based on voluntary participation - were determined to be the experimental group. One of the classrooms was a morning class, and the other was an afternoon class. With the assumption that the demographic characteristics of the children and their parents in the same neighborhood would be similar, the morning and afternoon classrooms of another kindergarten - which was similar to the experimental group and in accordance with the criterion sampling criteria - were selected as the control group. In this way, it was aimed to minimize the likelihood that the children and the teachers in the control group were affected by the implementation that was being carried out. After the necessary permits were obtained from the Directorate of National Education of Afyonkarahisar Province, the parents of the children who were included in the sample were each sent an "informed consent form" for research permission. Accordingly, 70 children ( 15 girls and 20 boys in the experimental group, and 18 girls and 17 boys in the control group) whose forms were signed by their parents were included in the study. The sample of the qualitative dimension of the study consisted of the classroom teachers of the children who were in the experimental group.

The early academic and language skills, mathematical development and print awareness levels of the experimental and control groups are given in Table 1, according to the pretests that were administered before the education began.

Table 1. Independent Samples t-Test Results According to the Pretest Scores of the Children in the Experimental and Control Groups

\begin{tabular}{ccccccc}
\hline Tests & Group & $\mathrm{n}$ & $\overline{\mathbf{X}}$ & $\mathrm{sd}$ & $\mathrm{t}$ & $\mathrm{p}$ \\
\hline \multirow{2}{*}{ K-Seals } & Experimental & 35 & 53 & 10 & -.427 & .671 \\
& Control & 35 & 54 & 7 & & \\
\multirow{2}{*}{ Progress in Math 6 } & Experimental & 35 & 10 & 4 & \multirow{2}{*}{.072} & .943 \\
& Control & 35 & 10 & 2 & & \\
Print Awareness & Experimental & 35 & 9 & 3 & -.676 & .502 \\
\hline
\end{tabular}

$\mathrm{p}<.05$

According to Table 1, there were no significant differences between the K-Seals $(\mathrm{t}=-.427, \mathrm{p}>.05)$, Progress in Math 6 $(\mathrm{t}=.072, \mathrm{p}>.05)$ and Print Awareness $(\mathrm{t}=-.676, \mathrm{p}>.05)$ pretest scores of the children in the experimental and control groups. Based on this result, it can be said that the children in the experimental and control groups had similar characteristics in terms of early academic and language skills, mathematical development and print awareness when the education began.

\subsection{Data Collection Instruments}

In the study, the "General Information Form" developed by the researchers to collect personal information about the children and their parents, the "Kaufman Survey of Early Academic and Language Skills," "Progress in Maths 6 Test," and "Control List for the Evaluation of the Print Awareness of Pre-School Children" were used.

\subsubsection{General Information Form}

The form included questions about the gender of the child, the number of siblings, the educational level of parents and whether the child received any previous preschool education. The general information forms were filled out by the researchers for each child based on information from the children's personal development files in the schools. 


\subsubsection{Kaufman Survey of Early Academic and Language Skills (K-SEALS)}

The original form of the Kaufman Survey of Early Academic and Language Skills, developed by Kaufman and Kaufman (1993) in America, provides the evaluation of early language, cognitive proficiency and academic skills of children aged 36-83 months. K-SEALS consists of three sub-tests to cover the early academic and language skills of children, including Vocabulary, Numbers, Letters \& Words and Articulation Survey. It has four scales, including Expressive Language Skills, Receptive Language Skills, Number Skills and Letter \& Word Skills, based on the sub-tests. And, it includes the Early Academic and Language Skills Composite consisting of the collection of the Vocabulary, Numbers and Letters \& Words sub-tests. The raw score for each sub-test is the number of items that have been correctly answered (Kaufman and Kaufman, 1993). It was found that the one-dimensional factor structure was confirmed according to the results of the confirmatory factor analysis of the K-SEALS collection (90 items) adapted to Turkish by Uyanık and Kandır (2014). The KR-20 reliability coefficient for the K-SEALS was determined to be .971 , and the item total correlation coefficient of the majority of the items were found to be at a high level of reliability. The test-retest correlation for the K-SEALS total was found to be .908 . In this study, analyses were carried out based on the K-SEALS total scores.

\subsubsection{Progress in Math 6}

The original form of the test was developed, and its validity and reliability studies were carried out by Clausen, Vappula and Ruddock in England in 2004. The validity and reliability studies of the test conducted in England was carried out for children aged 4-14 years. The Progress in Math 6 test is divided into numbers, shapes, fields, measurements, data analysis and use categories as content categories. Moreover, the test items are divided into process categories of knowledge of facts and methods, using concepts, solving daily problems, and reasoning. The test consists of 24 items in total and lasts approximately 35 minutes. When evaluating the test, 1 point is given for each correct answer and 0 points for each wrong answer. As a result of the adaptation of the test to Turkish, and its validity and reliability studies by Çelik and Kandir (2011), all of the items were determined to be fit for content validity. The alpha correlation was found to be .80 , and KR-20=.81. According to the results of the analysis, the test-retest correlation was determined as .95 .

\subsubsection{The Control List for the Evaluation of the Print Awareness of Pre-School Children}

This was developed by Şimşek Çetin and Alisinanoğlu (2013) in order to assess preschool-age children's print awareness. The control list was prepared to evaluate preschool-age children's level of knowledge related to book concepts, function of writing, shape of writing, direction of writing, and writing-related concepts such as sentences, words and letters. A test record form for each child and two storybooks titled the "Colored Feather" and "Ömer is Baking a Cake" are used in the control list. The control list has a total of 17 items, and each item is given 1 point if the child gives a correct answer, and 0 points if the child gives an incorrect answer. The highest score that can be obtained from the checklist is 17, and the lowest score is 0 . As the score received increases, children's print awareness level is considered to be high. The control list is administered individually for each child, and it takes approximately 10 minutes. Experts were consulted for the content validity of the control list. An exploratory factor analysis (EFA) was carried out on 200 children, and a confirmatory factor analysis (CFA) was carried out on 200 children for the construct validity of the list. Based on the validity study, the control list was found to consist of 17 items and a two-factor structure. The first dimension was called "Book Concepts," and the second dimension was called "Writing Concepts." The KR-20 reliability coefficient for the entire control list was calculated as .72 (Şimşek Çetin \& Alisinanoğlu, 2013).

\subsubsection{Teacher Interview Form}

It was developed by the researchers to evaluate teachers' views on the experimental implementation process. Semi-structured interviews were conducted with the teachers to understand whether the studies carried out in the learning centers contributed to the teachers' personal/professional development, and what the impact of the learning centers that were created or reorganized in the classroom was on the children's language and early academic skills. Data were gathered through in-depth and one-to-one interviews (Creswell, 1998; Denzin \& Lincoln, 1994). The Teacher Interview Form was given its final shape after expert opinions and pilot testing.

\subsubsection{Learning Centers}

It was aimed in the "Learning Centers" to help the children develop language, early literacy and mathematical skills by letting them interact with materials that attract their attention and allow them to use their senses effectively. To that end, it was determined as the primary objective to allow the children to discover, understand and develop their 
language, early literacy and math skills through sensory experiences when choosing the materials planned to be used in the learning centers. In this respect, the following were reviewed: relevant literature analyses; the curricula and materials of preschool educational approaches such as Montessori, High Scope, and Regio Emilia; and the gains, indicators and concepts found in the MoNE Preschool Education Program (2013).

In order to support children's skills, it was decided to create block, dramatic play, art, book, science/mathematics, early literacy skills and music centers in the educational environment. It was aimed to stimulate the senses and have children gain various skills through the presentation of the materials in the learning centers systematically and sequentially to the children and through the experiences obtained with the help of the materials. Accordingly, all tables, chairs, shelves and educational materials in the educational environment were examined and cleaned, grouped and listed in the experimental group before the implementation was initiated. The educational environment was transformed into an ideal classroom environment by ensuring the transfer of unnecessary materials into the school warehouse. In addition to the educational materials found in the classroom, new materials were purchased or prepared in order to improve the targeted skills. It was planned in advance which materials to be added to the learning centers and how to organize them each week. It was decided to add stuff and make revisions in the block, music and dramatic play centers once a week (Mondays), and in the mathematics, early literacy skills, book and art centers twice a week (Mondays and Wednesdays).

The learning centers were organized in a way that allows 35 children to use them for eight weeks, each day of the week, for approximately 75-90 minutes per day. Before starting the experimental implementation, two teachers and teacher assistants in the sample were given detailed information on the content and objectives of the study to be carried out; what opportunities will be created in order to achieve the objectives; how to communicate with children; in what kind of a physical environment this communication would take place and with which stimulants and materials; and which methods and techniques to use. Moreover, the materials to be added to the learning centers were told one day in advance to the experimental group teachers and co-teachers. The materials were examined together to discuss what purpose they served and how to use them. And, they were allowed to practice the materials. The teachers and co-teachers had arranged the educational environment appropriately before the children arrived every day. Circle time activities were carried out in order to help the children prepare and adapt to the studies in the learning centers every day during the implementation. These activities lasted 15-20 minutes. During the circle time activities, first, discussions were held with the children, followed by studies related to a pre-determined concept and word such as photography and video shows, singing, finger-game playing and telling rhymes. Then, the children were divided into groups of 3-4 people according to the class size, by using methods such as drawing cards, playing numbers, asking the children at which learning centers they would like to play, or teacher guidance. The children in each group were given the opportunity to study in three to four learning centers at 15-20-minute time intervals on every day in such a way to always allow them to play games in at least two of the arts, science-mathematics, books and early literacy skills centers every day. In this process, the teachers and co-teachers observed the children. They guided them when needed in terms of how the children would use the materials and how they would play the games. They also played games with the children. Especially after the books in the book center were examined, a book that the children decided together was read by the teacher to the children through an interactive book-reading method. And then, a discussion about the book was held with the children. Evaluations were carried out by chatting with the children about the following topics: The concept/word discussed during the circle time activities in order to enable children to reach new conclusions from the gains they derived from the games; the kinds of games they played in each learning center; the products they produced; problems and solutions they encountered when producing the products; the centers and games they liked more; and whether there was a fun or sad event during games. The procedure was repeated in both groups who were receiving training in the morning and afternoon within the same day.

\subsection{Data Analysis}

In the study, descriptive statistics such as frequencies and percentages were used to assess demographic characteristics of the children. Based on the normality test of the scores obtained from the scales [Kolmogorov-Smirnoff (K-)], Independent Samples t-tests and paired-samples t-tests were used due to the normal distribution of the values. The significance level was set as .05. Cohen (1988) defined effect sizes as "small, d=.2", "medium, $\mathrm{d}=.5$ " and "large, $\mathrm{d}=.8 . "$

In the qualitative section of the study, the individual interviews that were recorded with a voice recorder were first transcribed. Since there were no predefined code lists, the data analysis began with inductive coding. The data collected from the interviews were subject to a line-by-line or word-by-word content analysis. The data were coded 
into two columns, one of which was reserved for codes and the other for themes. The related codes were gathered under suitable themes.

\section{Findings}

The results regarding the quantitative and qualitative data of the study conducted to investigate the impact of use of learning centers to support language and academic skills of children aged 61-72 months are presented below.

\subsection{Findings Regarding the Quantitative Data}

Table 2. Paired-Samples T-Test Results According to the Pretest-Posttest Scores of the Children in the Experimental Group

\begin{tabular}{cccccccc}
\hline Tests & Group & $\mathrm{n}$ & $\mathbf{\mathbf { X }}$ & $\mathrm{sd}$ & $\mathrm{t}$ & $\mathrm{p}$ & Cohen's d \\
\hline \multirow{2}{*}{ K-Seals } & Pretest & 35 & 53.3 & 9.7 & -6.8 & $.000^{*}$ & .83 \\
& Posttest & 35 & 60.8 & 8.1 & & & \\
\multirow{2}{*}{ Progress in Math 6 } & Pretest & 35 & 9.7 & 4.0 & -11.2 & $.000^{*}$ & 2.28 \\
& Posttest & 35 & 18.3 & 3.5 & & & \\
\multirow{2}{*}{ Print Awareness } & Pretest & 35 & 9.2 & 2.9 & -7.9 & $.000^{*}$ & \multirow{2}{*}{1.63} \\
& Posttest & 35 & 13.7 & 2.6 & & & \\
\hline
\end{tabular}

$* \mathrm{p}<.05$

Table 4 shows that the differences between the K-Seals $(\mathrm{t}=-6.8, \mathrm{p}<.05, \mathrm{~d}=.83)$, Progress in Math $6(\mathrm{t}=-11.2, \mathrm{p}<.05$, $\mathrm{d}=2.28)$ and Print Awareness $(\mathrm{t}=-7.9, \mathrm{p}<.05, \mathrm{~d}=1.63)$ pretest-posttest scores of the children in the experimental group were significant. These differences were found to be in favor of the posttest scores. According to these results, the learning centers can be said to affect the development of children's early academic and language skills, mathematical development and print awareness skills.

Table 3. Paired-Samples T-Test Results According to the Pretest-Posttest Scores of the Children in the Control Group

\begin{tabular}{cccccccc}
\hline Tests & Group & $\mathrm{n}$ & $\overline{\mathbf{X}}$ & $\mathrm{sd}$ & $\mathrm{t}$ & $\mathrm{p}$ & Cohen's d \\
\hline K-Seals & Pretest & 35 & 54.1 & 6.8 & -2.5 & $.016^{*}$ & .42 \\
& Posttest & 35 & 56.9 & 6.4 & & & \\
Progress in Math 6 & Pretest & 35 & 9.7 & 2.5 & -3.3 & $.003^{*}$ & 3.48 \\
& Posttest & 35 & 10 & 2.5 & & & \\
Print Awareness & Pretest & 35 & 9.7 & 3.1 & -.723 & .475 & - \\
& Posttest & 35 & 10.1 & 2.3 & & & \\
\hline
\end{tabular}

$* \mathrm{p}<\overline{.05}$

Table 3 shows that the difference between the Print Awareness pretest and posttest scores of the children in the control group ( $\mathrm{t}=-. .723, \mathrm{p}>.05)$ was found to be insignificant, while the differences between their K-Seals $(\mathrm{t}=-2.5$, $\mathrm{p}<.05, \mathrm{~d}=.42)$ and Progress in Math $6(\mathrm{t}=-3.3, \mathrm{p}<.05, \mathrm{~d}=3.48)$ pretest and posttest scores were found to be significant. These differences were found to be in favor of the posttest scores.

It was seen that the K-Seals and Progress in Math 6 posttest scores were significantly higher than the pretest scores in the control group. Because the same was true also in the experimental group, the differences related to the posttest and pretest scores of the variables were obtained to determine in which group the posttests of the relevant scores were higher. The resulting difference scores are given in Table 4. 
Table 4. Independent Samples T-Test Results According to the Posttest-Pretest Score Differences of the Children in the Experimental and Control Groups

\begin{tabular}{cccccccc}
\hline Tests & Group & $\mathrm{n}$ & $\overline{\mathbf{X}}$ & $\mathrm{sd}$ & $\mathrm{t}$ & $\mathrm{p}$ & Cohen's d \\
\hline K-Seals & Experimental & 35 & 7.5 & 6.5 & 3.071 & $.003^{*}$ & .72 \\
$\begin{array}{c}\text { (Difference between } \\
\text { posttest and pretest) }\end{array}$ & Control & 35 & 2.8 & 6.5 & & & \\
Progress in Math 6 & Experimental & 35 & 8.6 & 4.5 & 10.813 & $.000^{*}$ & 2.59 \\
$\begin{array}{c}\text { (Difference between } \\
\text { posttest and pretest) } \\
\text { Print Awareness }\end{array}$ & Control & 35 & 0.3 & 0.5 & & & \\
$\begin{array}{c}\text { (Difference between } \\
\text { posttest and pretest) }\end{array}$ & Control & 35 & 0.4 & 3.3 & & & \\
\hline .05 & & & & & & & \\
\end{tabular}

Table 4 shows that that there were significant differences between the experimental and control groups in terms of the K-Seals $(\mathrm{t}=3.071, \mathrm{p}<.05, \mathrm{~d}=.72)$, Progress in Math $6(\mathrm{t}=10.813, \mathrm{p}<.05, \mathrm{~d}=2.59)$ and Print Awareness $(\mathrm{t}=5.199$, $\mathrm{p}<.05, \mathrm{~d}=1.24)$ difference scores. Accordingly, it was observed that the difference scores of the experimental group were significantly higher than that of the control group.

Table 5. Independent Samples T-Test Results According to the Posttest Scores of the Children in the Experimental and Control Groups

\begin{tabular}{cccccccc}
\hline Tests & Group & $\mathrm{n}$ & $\overline{\mathbf{X}}$ & $\mathrm{sd}$ & $\mathrm{t}$ & $\mathrm{p}$ & Cohen's d \\
\hline K-Seals & Experimental & 35 & 61 & 8 & 2.227 & $.029^{*}$ & .56 \\
& Control & 35 & 57 & 6 & & & \\
Progress in Math 6 & Experimental & 35 & 18 & 3 & 11.553 & $.000^{*}$ & 3.13 \\
& Control & 35 & 10 & 2 & & & \\
Print Awareness & Experimental & 35 & 14 & 3 & 6.141 & $.000^{*}$ & 1.56 \\
& Control & 35 & 10 & 2 & & & \\
\hline
\end{tabular}

${ }^{*} \mathrm{p}<.05$

Considering Table 5, according to the results of the Independent Samples t-test, it was found that there were significant differences between the K-Seals $(\mathrm{t}=2.227, \mathrm{p}<.05, \mathrm{~d}=.56)$, Progress in Math $6(\mathrm{t}=11.553, \mathrm{p}<.05, \mathrm{~d}=3.13)$ and Print Awareness ( $\mathrm{t}=6.141, \mathrm{p}<.05, \mathrm{~d}=1.56$ ) posttest scores of the children in the experimental and control groups. Based on this result, it was understood that the early academic and language skills, mathematics development and print awareness scores of the children in the experimental group were higher those of the children in the control group.

\subsection{Findings Regarding the Qualitative Data}

The findings regarding the qualitative data obtained through the interviews with the teachers were analyzed under five main themes.

a. The Effect on Teachers' Professional Development

Teachers explained that they gained experience about the diversity of materials placed in learning centers to develop language, mathematics and early literacy skills. In addition, they said they gained experience about the methods and techniques used in the game process with the materials. They explained that they improved themselves in terms of using the materials more effectively. In particular, they expressed that they learned how to build a center for early literacy skills and how to guide children. They explained that the implementation process affected their professional development.

Teacher A: It was a very good process, especially to learn the diversity, quality and use of materials placed in language, mathematics and early literacy centers. I have acquired new ideas especially in terms of preparing centers for phonological and print awareness and developing learning processes. 
Teacher B: I have developed a new perspective on the diversity of materials in the center for mathematics and literacy and the process of guiding children. The materials for phonological and print awareness and the circle time activities helped me gain awareness about the work I can do in this area.

\section{b. The Effect on Development of Children's Language Skills}

The teachers stated that the studies conducted in the learning centers had positive effects on the children's ability to use language for communication, the richening of their vocabulary, and their ability to form sentences complying with grammar and syntax rules.

Teacher A: With the interactive book-reading technique, the children have advanced in terms of being more effective listeners. Playing small group games with different group mates in the learning centers allowed to increase the bond between the children who were communicating very little among themselves and to use the language for communication.

Teacher B: The conversations during the circle time activities and the studies in the learning centers have contributed to the development of children's vocabulary and especially to their ability to build sentences according to the syntax rules and grammar rules. During the day, after the implementation, they wanted to continue to do studies in other activities by using the materials placed in the learning centers. They are eager to share what they experience in the learning centers with each other and with me. I'm getting feedback on their sharing what they do in the learning centers with their parents in dialogs at great length after school.

c. The Effect on Development of Children's Early Literacy Skills

The teachers explained that studies in the learning centers let the children have awareness of the sounds at the beginning of, at the end of, and within words. They also explained that the children had increased their interest in sound games and books. They pointed out that the children were willing to examine written materials, and that they recognized the upper/lower-case and plain/italic letters, and punctuation marks. They stated that the studies that were carried out affected the children's readiness for elementary school.

Teacher A: The children's sensitivity to the sounds in the alphabet has increased. I observe that in conversations among themselves, in other events and when they are with their families, they are arguing especially about the first and last sounds of words. I believe that reading interactive books at the book center affects the children's ability to know why writing is important; to establish a relationship between reading direction, writing and pictures; and to understand and interpret what is being read to them.

Teacher B: Almost all children are correctly responding to questions related to words that begin and end with the same sound and related to the sound in the word. Their interest in sounds, the letters in the alphabet, and books has risen considerably. They have come to a level to distinguish the uppercase and lowercase letters, and plain and italic letters in the alphabet. When reviewing the written materials and reading books with the children, they initiate discussions on the beginning and end of the sentence and punctuation marks. The children are very ready for elementary school with these skills they have gained.

\section{d. The Effect on Development of Children's Math Skills}

The teachers explained that the individual and small group studies carried out in the learning centers affected the development of children's math skills such as comparison, matching, sorting, grouping, numbers, geometric shapes, operations, and measuring. At the same time, they stated that the children learned by observing each other or by discussion when playing games with materials.

Teacher A: Most of the children showed a lot of interest in the mathematical materials at the learning centers. While playing with the games in the centers, their experience with numbers, mathematical operations and geometric shapes has increased. The materials found in the math center supported the development of children's skills such as comparisons, matching, sorting, patterns, numbers, operations, and measurements without their knowledge.

Teacher B: Since the children have studied with the materials that are found in the math center individually and in small groups, they completed their deficiencies in mathematical skills or what they were missing by observing each other closely or by discussing them together. We have had a good opportunity to observe the children closely and to recognize the skills they lack when they were playing games with the materials.

As a result, when the opinions of the teachers are examined, it can be said that the arrangement of the learning centers and the studies that were carried out contributed to the professional development of the preschool teachers in line with their philosophies and principles. At the same time, it can be said that the circle time activities and the studies carried out in the learning centers were effective in the development of children's language, early literacy and 
math skills. It can be said that the children's early academic and language skills were activated with the planned learning processes focused on the studies done through conversations during the circle time activities and the materials in the learning centers, and that the rich materials offered in the educational environment were found to be very interesting for children and facilitated the learning process.

\section{Discussion}

In this study, the impact of use of learning centers to support language skills and academic skills of children aged 61-72 months was researched. It was found, based on the study, that when the K-Seals, Progress in Math 6 and Print Awareness posttest mean scores of the children in the experimental and control groups were compared, there was a statistically significant difference in favor of the experimental group $(\mathrm{p}<.05)$. And, the difference between the Print Awareness pretest and posttest scores of the children in the control group was found to be insignificant, while the differences between their K-Seals and Progress in Math 6 pretest and posttest scores were found to be significant. According to the difference scores obtained from the two groups, the change in the experimental group can be said to be significant, whereas the change in the control group can be said to be random. Moreover, the statistically significant increase in the K-Seals and Progress in Math 6 scores of the children in the control group is also thought to possibly originate from the fulfillment of the gains and indicators in the MoNE Preschool Education Program (2013) administered to the children and from the development of academic and linguistic skills of the children during the research process. However, the results obtained from the interviews with the experimental group teachers in the qualitative section of the research show that the studies that were conducted in the learning centers had significant contributions to the development of children's language, early literacy and math skills. Consequently, learning centers were found to be effective in supporting the language and academic skills of children aged 61-72 months.

During the implementation, discussions were held with the children about various concepts during the circle time activities. They were given opportunity to express and discuss their prior experiences and knowledge about these concepts and words. Moreover, the active participation of all children was supported in these environments by offering them enriched environments in the learning centers. It is seen that the activities offered to the children and the active studies in the learning centers during the implementation were effective in promoting the language and academic skills of the children.

Research paralleling the results obtained from this study have been reported in the literature, and the following studies could be found: Burchinal et al. (2008) determined that the quality of the educational environment in preschool education institutions attended by 4-year-old children experiencing academic problems due to low socio-economic level has an impact on children's language and early academic skills. Keys et al. (2013) have evaluated the quality of preschool education institutions attended by 6,250 children aged 3-6 years, by using ECER-S (the early childhood environment rating scale-revised). They have determined that the quality of classroom affects children's mathematics and literacy skills. Uyanık Aktulun et al. (2018) have found that playing games every day in the preschool period for eight weeks in specially-arranged learning centers is effective in supporting children's cognitive, language, social-emotional and motor development areas. Einarsdottir (2014) has found that richening literacy preparation materials in game centers affects the development of children's readiness for literacy skills. The research studies given above have emphasized that the quality of a classroom is effective in supporting children's language, early literacy and math skills. They parallel the results of this present study. However, there are also studies in the literature showing that the quality of a classroom has little or no effect on children's language, literacy and math development (Burchinal et al. 2010; Weiland, Ulvestad, Sachs, \& Yoshikawa, 2013).

It is one of the attention-grabbing results of this study that there was a significant increase in math skills of the children in the experimental group compared to those of the children in the control group. During the implementation process, the children were able to actively work individually or in small groups with materials related to math skills placed in the math center under the guidance of the teachers when necessary. It can be said that this process has contributed to the development of children's math skills. Laski, Jor'dan, Daou \& Murray (2015) have found that children's spending their time with math-related educational materials is effective on their problems solving, critical thinking and mathematical learning. Holmes (2013) conducted a meta-analysis study between 1989 and 2012. As a result of this study, it was revealed that educational materials were effective in the mathematics achievement of Independent Sampless from preschool to 12th grade. Erdoğan, Parpucu and Boz (2017) have determined that educational materials related to numbers and operations affect math skills of preschool children. These research studies support the importance of educational materials in the development of math skills and parallel the results of this present study. 
It is another attention-grabbing result of this study that there was a significant increase in the language and early literacy scores of the children in the experimental group compared to those of the children in the control group. It can be said that the interactive book-reading method used in the implementation process and the work done in accordance with this method contributed to the development of children's language and early literacy skills. Research has shown that interactive book-reading studies carried out in the preschool period support children's vocabulary and expressive language skills (Lever \& Senechal, 2011), recipient and expressive language skills (Akoğlu, Ergül \& Duman, 2014) and print awareness skills (Efe \& Temel, 2018). These research studies support the finding that interactive book-reading studies carried out in book centers affect the development of children's language and literacy skills.

\section{Conclusion and Recommendations}

Limitations of the study should also be considered when assessing the results of the study, where learning centers were determined to be effective in supporting the language and academic skills of 61-72-month-old children. In this study, the findings regarding the children are limited to the number of children in the sample and the studies carried out in the learning centers, which were created and re-organized in classrooms. Another limitation of the study is that no follow-up study was carried out. Based on the findings of the study, the following recommendations can be made:

Teachers and teacher candidates who work in the field must be supported in terms of professional knowledge and skills in order to create educational environments with rich stimuli that provide children with different learning experiences in preschool education institutions.

Learning centers should be organized in accordance with the purpose of the study in preschool education institutions where children of different sociocultural levels are educated. The study should be repeated, and the data to be obtained should be compared.

The long-term effects of the experimental study should be investigated. In addition, the effect of establishing high-quality learning centers on children's different skills (reasoning, social skills, communication skills, and so forth) should be examined.

\section{References}

Akoğlu, G., Ergül, C., \& Duman, Y. (2014). Etkileşimli kitap okuma: korunmaya muhtaç çocukların alıcı ve ifade edici dil becerilerine etkileri. Illkögretim Online, 13(2), 622-639.

Allen, D., \& Fraser, B. (2007). Parent and Independent Samples perceptions of classroom learning environment and its association with Independent Samples outcomes. Learning Environment Research, 10(1), 67-82. https://doi.org/10.1007/s10984-007-9018-z.

Anders, Y., Rossbach, H. G., Weinert, S., Ebert, S., Kuger, S., Lehrl, S., \& von Maurice, J. (2012). Home and preschool learning environments and their relations to the development of early numeracy skills. Early Childhood Research Quarterly, 27(2), 231-244. https://doi.org/10.1016/j.ecresq.2011.08.003

Aysu, B., \& Aral, N. (2016). Okul öncesi öğretmenlerinin öğrenme merkezleri hakkındaki görüş ve uygulamalarının incelenmesi. Kastamonu Eğitim Dergisi, 24(5), 2561-2574.

Backman, Y., Alerby, E., Bergmark, U., Gardelli, Å., Hertting, K., Kostenius, C., \& Öhrling, K. (2012). Improving the school environment from a Independent Samples perspective: tension and opportunities. Education Inquiry 3(1), 19-35. https://doi.org/10.3402/edui.v3i1.22011

Barnett, W. S. (2011). Effectiveness of early educational intervention. Science, 333(6045), 975-978. https://doi.org/10.1126/science.1204534.

Beaty, J. J. (2014). Preschool appropriate practices: environment, curriculum and development (4th Ed.). Belmont, CA: Wadsworth Cengage Learning.

Biddle, K. A. G., Garcia-Nevarez, A., Henderson, W. J. R., \& Valero-Kerrick, A. (2013). Early childhood education: Becoming a professional. Los Angeles: SAGE.

Burchinal, M., Howes, C., Pianta, R., Bryant, D., Early, D., Clifford, R., \& Barbarin, O. (2008). Predicting child outcomes at the end of kindergarten from the quality of pre-kindergarten teacher-child interactions and instruction. Applied Development Science, 12, 140-153. https://doi.org/10.1080/10888690802199418

Burchinal, M., McCartney, K., Steinberg, L., Crosnoe, R., Friedman, S. L., McLoyd, V., et al. (2011). Examining the 
black-white achievement gap among low-income children using the NICHD study of early child care and youth development. Child Development, 82, 1404-1420. https://doi.org/10.1111/j.1467-8624.2011.01620.x.

Burchinal, M., Peisner - Feinberg, E., Pianta, R., \& Howes, C. (2002). Development of academic skills from preschool through second grade: family and classroom predictors of developmental trajectories. Journal of School Psychology, 40(5), 415-436. https://doi.org/10.1016/S0022-4405(02)00107-3

Burchinal, M., Vandergrift, N., Pianta, R., \& Mashburn, A. (2010). Threshold analysis of association between child care quality and child outcomes for low-income children in pre-kindergarten programs. Early Childhood Research Quarterly, 25(2), 166-176. https://doi.org/10.1016/j.ecresq.2009.10.004.

Campbell, A. F., Pungello, P. E., Miller-Johnson, S., Burchinal, M., \& Ramey, T. C. (2001). The development of cognitive and academic abilities: Growth curves from an early childhood educational experiment. Developmental Psychology, 37(2), 231-242. http://dx.doi.org/10.1037/0012-1649.37.2.231

Cohen, J. (1988). Statistical power analysis for the behavioral sciences (2nd ed.). Hillsdale, NJ: Lawrence Earlbaum Associates.

Cohen, L, Manion, L., \& Morrison, K. (2010). A guide to teaching practice (5th ed.). London: Routledge.

Conn-Powers, M. C. (2010). Early Childhood School Readiness series 2: Preparing children for kindergarten: learning centers. $\quad$ Retrieved October 20, 2018. from https://www.iidc.indiana.edu/styles/iidc/defiles/ECC/LearningCenters.pdf

Creswell, J. W. (1998). Qualitative inquiry and research design: choosing among five traditions. Thousand Oaks, CA: Sage.

Creswell, J. W., \& Clark, V. L. P. (2017). Designing and conducting mixed methods research. Sage publications.

Çelebi Öncü, E. (2017). Okul öncesi çocuklarının sınıflarında yapılandırdıkları öğrenme merkezlerinin incelenmesi. Kastamonu Ĕgitim Dergisi, 25(2), 733-746.

Çelik, M., \& Kandır, A. (2011). Matematik Gelişimi 6 Testi (Progress in Math 6) nin 60-77 aylar arasında olan çocuklar için geçerlik ve güvenirlik çalışması. Kuramsal Eğitim Bilim Dergisi, 4(1), 146-153.

DaCunha, D. (2016). iPads and preschool: Integrating iPads into a preschool classroom to support learning centers and phonological awareness. (Unpublisehed Doctoral dissertation). The William Paterson University, New Jersey, United States.

Dahmer, M. C. (2010). Phonological awareness in the kindergarten classroom: How do teachers perceive this essential link from oral communication to reading skill development. (Unpublished doctoral dissertation). Liberty University, Virginia, United States.

Denzin, N. K., \& Lincoln, Y. S. (Eds.). (1994). Handbook of qualitative research. CA: Sage.

Devany, M. (2005). Why I organized learning centers in my classroom. Teaching Music, 13(1), 44-48.

Duncan, G. J., Dowsett, C. J., Claessens, A., Magnusson, K., Huston, A. C., Klebanov, P., . . Japel, C. (2007). School readiness and later achievement. Developmental Psychology, 43(6), 1428-1446. https://doi.org/10.1037/0012-1649.43.6.1428.

Dyment, J., \& O'Connell, T.S. (2013). The impact of playground design on play choices and behaviors of preschool children. Children's Geographies, 11(3), 263-280. https://doi.org/10.1080/14733285.2013.812272

Efe, M., \& Temel, Z. F. (2018). Okul öncesi dönem 48-66 ay çocuklarına etkileşimli kitap okuma programı'nın yazı farkındalığına etkisinin incelenmesi. Erken Çocukluk Çalışmaları Dergisi, 2(2), 257-283. https://doi.org/10.24130/eccd-jecs.196720182257

Einarsdottir, J. (2014). Play and literacy: a collaborative action research project in preschool Scandinavian. Journal of Educational Research, 58(1), 93-109. https://doi.org/10.1080/00313831.2012.70532.

Erdoğan, S., Parpucu, N., \& Boz, M. (2017). Sayı ve işlemlerle ilgili eğitim materyallerinin okul öncesi dönem çocuklarını matematik becerisine etkisi. Illkögretim Online, 16(4), 1777-1791. https://doi.org/10.17051/ilkonline.2017.342991.

Gandini, L. (1998). Educational and caring spaces. In C. Edwards, L. Gandini, \& G. Forman (Eds.), The hundred languages of children: The Reggio Emilia approach-advanced reflections (2nd ed., pp. 161-178). Norwood, NJ: Ablex. 
Hebert, E. (1998). Design matters: How school environment affects children. Educational Leadership, 56(1), 69-70.

Hilberg, R. S., Chang, J. M., \& Epaloose, G. (2003). Designing effective activity centers for diverse learners. Santa Cruz, CA, USA: Center for Research on Education, Diversity \& Excellence, University of California. Retrieved October 20, 2018 from http://manoa.hawaii.edu/coe/crede/wp-content/uploads/Hilberg_et_al_20031.pdf

Holmes, A. B. (2013). Effects of manipulative use on PK-12 mathematics achievement: A meta analysis. Poster presented at the meeting of Society for Research in Educational Effectiveness, Washington, DC. Retrieved October 20, 2018 from https://files.eric.ed.gov/fulltext/ED563072.pdf

Howes, C., Burchinal, M., Pianta, R., Bryant, D., Early, D. M., Clifford, R. M., et al. (2008). Ready to learn? Children's pre-academic achievement in prekindergarten programs. Early Childhood Research Quarterly, 23(1), 27-50. https://doi.org/10.1016/j.ecresq.2007.05.002

Jackman, H., Beaver, N., \& Wyatt, S. (2014). Early education curriculum: A child's connection to the world (6th Ed.). Stamford, USA: Cengage Learning.

Kandır, A., Özbey, S., \& İnal, G. (2010). Okul öncesi eğitimde program: kuramsal temeller. İstanbul: Morpa Kültür Yayınları.

Kaufman, A.S., \& Kaufman, N.L. (1993). K-SEALS Kaufman survey of early academic and language skills: Manual. Minneapolis: Pearson Assessments

Keys, T. D., Farkas, G., Burchinal, M. R., Duncan, G. J., Vandell, D. L., Li, W., ... \& Howes, C. (2013). Preschool center quality and school readiness: Quality effects and variation by demographic and child characteristics. Child development, 84(4), 1171-1190. https://doi.org/10.1111/cdev.12048.

King-Sears, M. E. (2007). Designing and delivering learning center instruction. Intervention in School and Clinic, 42(3), 137-147.

Kostelnik, M. J., Soderman, A. K., Whiren, A. P., \& Rupiper, M. L. (2015). Developmentally Appropriate Curriculum: Best practices in early childhood education (6th ed.). Upper Saddle River, NJ: Prentice Hall.

Laski, E., Jor'dan, J., Daou, C., \& Murray, A. (2015). What makes mathematics manipulatives effective? Lessons from cognitive science and montessori education. SAGE Open, 1-8.

Lever, R., \& Senechal, M. (2011). Discussing stories: On how a dialogic reading intervention improves kindergartners' oral narrative construction. Journal of Experimental Child Psychology, 108, 1-24. https://doi.org/10.1016/j.jecp.2010.07.002

Li, Y. L. (2006). Classroom organization: Understanding the context in which children are expected to learn. Early Childhood Education Journal, 34(1), 37-43. https://doi.org/10.1007/s10643-006-0120-0

Mashburn, A. J., Pianta, R. C., Hamre, B. K., Downer, J. T., Barbarin, O. A., Bryant, D., ... \& Howes, C. (2008). Measures of classroom quality in prekindergarten and children's development of academic, language, and social skills. Child development, 79(3), 732-749. https://doi.org/10.1111/j.1467-8624.2008.01154.x.

Milli Eğitim Bakanlığı (MEB) [MONE] (2013). Okul öncesi eğitim programı. Ankara: Milli Eğitim Bakanlığı Temel Eğitim Genel Müdürlüğü Yayınları.

Metin, S. (2017). Investigation of the practices in learning centers of pre-school education institutes. Turkish Journal of Education, 6(1), 1-16. https://doi.org/10.19128/turje.267357.

Mokrova, I., Broekhuizen, M., \& Burchinal, M. (2015). Pre-kindergarten and kindergarten classroom quality and children's social and academic skills in early elementary grades. Society for Research on Educational Effectiveness. Retrieved October 20, 2018 from https://files.eric.ed.gov/fulltext/ED562445.pdf

Moore, G., \& Sugiyama T. (2007). The children's physical environment rating scale (CPERS): reliability and validity for assessing the physical environment of early childhood educational facilities. Children, Youth and Environment, 17(4), 24-53.

Naimoli-Ginter, C. (2008). Reducing aggressive behaviors of preschool children at learning centers through teacher selected groups (Unpublished doctoral dissertation). Caldwell College, New Jersey, United States.

Öztürk Samur, A., \& İnal Kızıltepe, G. (2018). An investigation of learning centres for effective learning. In R. Efe, I. Koleva \& E. Atasoy (Eds.) Recent Researches in Education (pp. 1-16). London: Cambridge Scholars Publishing. 
Pelatti, C. Y., Dynia, J. M., Logan, J. A., Justice, L. M., \& Kaderavek, J. (2016). Examining quality in two preschool settings: Publicly funded early childhood education and inclusive early childhood education classrooms. Child \& Youth Care Forum, 45(6), 829-849. https://doi.org/10.1007/s10566-016-9359-9.

Pellegrino, A. M. (2007). How can learning centers be used to support classroom instruction and promote critical thinking in a kindergarten classroom? (Unpublished master thesis). Rowan University, New Jersey, United States.

Ramani, G. B., \& Eason, S. H. (2015). It all adds up: Learning early math through play and games. Phi Delta Kappan, 96(8), 27-32. https://doi.org/10.1177/0031721715583959.

Ramazan, O., Çiftçi, H. A., \& Tezel, M. (2018). Okul öncesi sınıflarındaki öğrenme merkezlerinin durumunun belirlenmesi ve öğretmenlerin öğrenme merkezleri hakkındaki görüşlerinin incelenmesi. Erken Çocukluk Çalışmaları Dergisi, 2(2), 213-233. https://doi.org/10.24130/eccd-jecs.196720182258.

Robinson, E., \& Fraser, B. J. (2013). Kindergarten Independent Sampless' and parents' perceptions of science classroom environments: Achievement and attitudes. Learning Environments Research, 16(2), 151-167. https://doi.org/10.1007/s10984-013-9138-6.

Son, S. H., \& Morrison, F. J. (2010). The nature and impact of changes in home learning environment on development of language and academic skills in preschool children. Developmental psychology, 46(5), 1103-1118. https://doi.org/10.1037/a0020065.

Şimşek Çetin, Ö., \& Alisinanoğlu, F. (2015). Okul öncesi dönemdeki çocuklarin yazi farkindaliğini değerlendirme kontrol listesi'nin geçerlik ve güvenirlik çalışması. Karadeniz Sosyal Bilimler Dergisi, 5(8), 15-27.

Texas Workforce Commission, (2002). Learning centers -why and how. Texas Child Care, 25(4), 30-42.

Uyanık Aktulun, Ö., Can Yaşar, M., Karaca, N.H., Akyol, T., Şenol, F. B., \& Kaya, Ü.Ü. (2018). Oyun hakkı; Daha fazla oyun projesi. Türkiye Sosyal Araştırmalar Dergisi, Özel Sayl, 17-33.

Uyanık, Ö., \& Kandır, A (2014). Kaufman Erken Akademik ve Dil Becerileri Araştırma Testi'nin 61-72 aylık Türk çocuklarına uyarlanması. Kuram ve Uygulamada Eğitim Bilimleri 14(2), 669-692. https://doi.org/10.12738/estp.2014.2.1682

Uyanık, Ö., \& Alisinanoğlu, F. (2016). Akademik ve dil becerileri eğitim programının 61-66 aylık çocukların bilişsel yetenekleri ile erken akademik ve dil becerilerine etkisi. Mediterranean Journal of Humanities, VI(2), 459-481. https://doi.org/10.13114/MJH.2016.310

Weiland, C., Ulvestad, K., Sachs, J., \& Yoshikawa, H. (2013). Associations between classroom quality and children's vocabulary and executive function skills in an urban public prekindergarten program. Early Childhood Research Quarterly, 28(2), 199-209. https://doi.org/10.1016/j.ecresq.2012.12.002

Wright, L. M. (2016). How does play in dramatic play centers help preschool children develop oral language and literacy skills? (Unpublished doctoral dissertation). Walden University, Minneapolis, United States. 